University of Nebraska - Lincoln

DigitalCommons@University of Nebraska - Lincoln

Faculty Papers and Publications in Animal

Science

Animal Science Department

2008

\title{
Evaluation and application of the CPM Dairy Nutrition model
}

\author{
L. O, Tedeschi \\ Texas A\&M University \\ W. Chalupa \\ University of Pennsylvania \\ E. Janczewski \\ University of Pennsylvania \\ D. G. Fox \\ Cornell University \\ C. Sniffen \\ Fencrest LLC
}

See next page for additional authors

Follow this and additional works at: https://digitalcommons.unl.edu/animalscifacpub

Part of the Animal Sciences Commons

Tedeschi, L. O; Chalupa, W.; Janczewski, E.; Fox, D. G.; Sniffen, C.; Munson, R.; Kononoff, Paul J.; and Boston, R., "Evaluation and application of the CPM Dairy Nutrition model" (2008). Faculty Papers and Publications in Animal Science. 614.

https://digitalcommons.unl.edu/animalscifacpub/614

This Article is brought to you for free and open access by the Animal Science Department at DigitalCommons@University of Nebraska - Lincoln. It has been accepted for inclusion in Faculty Papers and Publications in Animal Science by an authorized administrator of DigitalCommons@University of Nebraska - Lincoln. 


\section{Authors}

L. O, Tedeschi; W. Chalupa; E. Janczewski; D. G. Fox; C. Sniffen; R. Munson; Paul J. Kononoff; and R. Boston 


\title{
MODELLING ANIMAL SYSTEMS PAPER Evaluation and application of the CPM Dairy Nutrition model
}

\author{
L. O. TEDESCHI ${ }^{1}$, W. CHALUPA ${ }^{2 *}$, E. JANCZEWSKI ${ }^{2}$, D. G. FOX ${ }^{3}$, C. SNIFFEN ${ }^{4}$, \\ R. MUNSON ${ }^{2}$, P. J. KONONOFF ${ }^{5}$ AND R. BOSTON ${ }^{2}$ \\ ${ }^{1}$ Department of Animal Science, Texas A\&M University, College Station, TX 77845, USA \\ ${ }^{2}$ School of Veterinary Medicine, University of Pennsylvania, Kennett Square, PA 19348, USA \\ ${ }^{3}$ Department of Animal Science, Cornell University, Ithaca, NY 14853, USA \\ ${ }^{4}$ Fencrest LLC, Holderness, NH 03245, USA \\ ${ }^{5}$ Department of Animal Science, University of Nebraska, Lincoln, NE 68583, USA
}

(Revised MS received 31 August 2007; First published online 30 November 2007)

\begin{abstract}
SUMMARY
The Cornell-Penn-Miner (CPM) Dairy is an applied mathematical nutrition model that computes dairy cattle requirements and the supply of energy and nutrients based on characteristics of the animal, the environment and the physicochemical composition of the feeds under diverse production scenarios. The CPM Dairy was designed as a steady-state model to use rates of degradation of feed carbohydrate and protein and the rate of passage to estimate the extent of ruminal fermentation, microbial growth, and intestinal digestibility of carbohydrate and protein fractions in computing energy and protein post-rumen absorption, and the supply of metabolizable energy and protein to the animal. The CPM Dairy version 3.0 (CPM Dairy 3.0) includes an expanded carbohydrate fractionation scheme to facilitate the characterization of individual feeds and a sub-model to predict ruminal metabolism and intestinal absorption of long chain fatty acids. The CPM Dairy includes a non-linear optimization algorithm that allows for least-cost formulation of diets while meeting animal performance, feed availability and environmental restrictions of modern dairy cattle production. When the CPM Dairy 3.0 was evaluated with data of 228 individual lactating dairy cows containing appropriate information including observed dry matter intake, the linear regression between observed and model-predicted milk production values indicated the model was able to account for $79 \cdot 8 \%$ of the variation. The concordance correlation coefficient (CCC) was high $\left(r_{\mathrm{c}}=0.89\right)$ without a significant mean bias $(0.52 \mathrm{~kg} / \mathrm{d} ; P=0 \cdot 12)$. The accuracy estimated by the CCC was 0.997 . The root of mean square error of prediction (MSEP) was $5 \cdot 14 \mathrm{~kg} / \mathrm{d}(0 \cdot 16$ of the observed mean) and $87 \cdot 3 \%$ of the MSEP was due to random errors, suggesting little systematic bias in predicting milk production of high-producing dairy cattle. Based upon these evaluations, it was concluded the CPM Dairy 3.0 model adequately predicts milk production at the farm level when appropriate animal characterization, feed composition and feed intake are provided; however, further improvements are needed to account for individual animal variation.
\end{abstract}

\section{INTRODUCTION}

For some years now, it has been evident that dairy cow nutrition models are vital to the continued success of the dairy industry. In addition, the production emphasis in several places in the world has shifted

* To whom all correspondence should be addressed. Email:wmchalupa@aol.com from milk volume and fat to include also milk protein concentration and yield. Mathematical models of ruminant nutrition have been employed for over three decades (Chalupa \& Boston 2003) and have stimulated improvements in feeding cattle. Accumulated research knowledge and complete data sets available in recent years combined with different mathematical approaches have led to improved nutrition models. 
Several mathematical models of ruminant nutrition have been developed in the past (Tedeschi et al. 2005) and it is likely that frequency of use will increase to support decision making not only in the nutrition of cattle, but also for other aspects including farm economics, animal management and assessment of environmental impact (Tylutki et al. 2004).

The Cornell-Penn-Miner (CPM) Dairy was a product of the combined effort by researchers at Cornell University, University of Pennsylvania and the W.H. Miner Agriculture Research Institute. The development of version 1 (CPM 1.0) was considered by Boston et al. (2000) who described the conversion of the Cornell Net Carbohydrate and Protein System (CNCPS 4.0; Fox et al. 2004) into this applied model that is being used by the dairy industry. The CNCPS and consequently the CPM Dairy have been used and evaluated using data from several places in the world.

Kolver et al. (1998) assessed the reliability of the CNCPS predictions for grazing dairy cows from four studies conducted in New Zealand and in the US. The authors reported the model provided good estimates of changes in body condition scores (BCS; $\left.R^{2}=0 \cdot 78\right)$, energy balance $\left(R^{2}=0.76\right)$, blood urea $\left(R^{2}=0.94\right)$, microbial N flow $\left(R^{2}=0.88\right)$, dry matter intake $\left(\mathrm{DMI} ; R^{2}=0 \cdot 80\right)$ and ruminal $\mathrm{pH}\left(R^{2}=0 \cdot 47\right)$. The predictions of milk production were sensitive to changes in pasture lignin content, physical effective fibre, rate of fibre digestion and amino acid composition of ruminal microbes. In addition, metabolizable energy (ME) was described to be the first limiting factor when lactating cows grazed high quality pastures.

In predicting milk production of individually fed high-producing dairy cows, Fox et al. (2004) indicated the CNCPS was able to account for $88 \%$ of the variation with a mean bias of $1.8 \mathrm{~kg} / \mathrm{d}$, which corresponds to 0.055 of the model predicted mean. These authors indicated that, when metabolizable protein (MP) was first limiting, the model adequacy was superior to when ME was first limiting.

More recently, using data from two experiments, Chaves et al. (2006) evaluated the CNCPS for grazing dairy cows supplemented with silages $(0 \cdot 30-0 \cdot 40$ of DMI). The authors observed no significant mean bias in predicting DMI, milk yield, or body weight (BW) changes. However, the precision $\left(R^{2}\right)$ of the model was lower than previously reported by Kolver et al. (1998) and Fox et al. (2004). It ranged from 51 to $59 \%$, indicating a satisfactory prediction of milk yield when cows were neither gaining nor losing BW, but a systematic bias was observed probably due to the partition of energy between milk yield and BW changes. Tedeschi et al. (2006) developed a model to account for changes in BW and/or BCS that are not accounted for when estimating ME- or MPallowable milk production from the intake above or below animal requirements for maintenance, pregnancy and growth. The authors recommended adjustment for BCS changes in a period longer than 7 days for accurate prediction of milk production of dairy cows.

The objectives of the current paper are: (1) to provide a description of the changes made to the CPM Dairy 1.0 in developing the CPM Dairy 3.0 and (2) to assess the adequacy of the CPM Dairy 3.0 in predicting milk production of high producing-lactating dairy cattle.

\section{MATERIAL AND METHODS Background}

The CPM Dairy 1.0 was originally programmed in Microsoft $C^{\mathrm{TM}}$ and was released in October 1998. The CPM Dairy 2.0 and 3.0 are 32-bit Microsoft Windows applications and were programmed in Microsoft Visual Basic $6.0^{\mathrm{TM}}$ and Microsoft $\mathrm{C}++6.0^{\mathrm{TM}}$ with a Microsoft Access $2000^{\mathrm{TM}}$ database capability to store input and output values. The CPM Dairy 2.0 was an intermediate release that allowed for software development and testing. It was only available for selected users of the CPM Dairy 1.0 to provide feedback on software design, focusing on field implementation and usability. Considerable effort was directed towards the development of the CPM Dairy 3.0 to meet the guidelines discussed by Newman et al. (2000) to be successfully used as a decision support system for dairy cattle.

\section{Development of the CPM Dairy 3.0}

The CNCPS model was developed to define more accurately rumen bacterial growth and whole animal requirements, to assess feed utilization and to predict production responses (Fox et al. 2004). The CNCPS was developed from basic principles of rumen function, microbial growth, feed digestion and passage rates and animal physiology. It also accounts for farm-specific management, environmental and feed characteristics. The system can be applied at the farm level because feeds are characterized according to fractions that are measured by most feed analysis laboratories. The CPM Dairy 3.0 is based on the CNCPS 5.0 level 2 of solution biological core (Fox et al. 2004). The main modifications towards the development of the CPM Dairy 3.0 were the inclusion of a new carbohydrate fractionation scheme (Lanzas et al. 2007) and a new lipid sub-model (Moate et al. 2004). A revised feed dictionary was added to support these additions.

\section{Carbohydrate fractionation scheme}

The comparison of carbohydrate fractionation schemes in CNCPS 5.0 and CPM Dairy 3.0 are 
Table 1. Composition and digestion of carbohydrate fractions in the CNCPS and CPM Dairy models

\begin{tabular}{|c|c|c|c|c|}
\hline \multicolumn{2}{|l|}{ Fractions } & \multirow[b]{2}{*}{ Composition } & \multirow[b]{2}{*}{$\begin{array}{l}\text { Ruminal } \\
\text { degradation } \\
\text { rate }(\% / \mathrm{h})\end{array}$} & \multirow[b]{2}{*}{$\begin{array}{l}\text { Intestinal } \\
\text { digestion } \\
(\mathrm{g} / \mathrm{kg})^{\mathrm{a}}\end{array}$} \\
\hline $\begin{array}{l}\text { CNCPS } 5.0 \text { and } \\
\text { CPM } 1.0\end{array}$ & СРM 3.0 & & & \\
\hline A & $\mathrm{A}_{1}$ & Silage acids & $1-2$ & 1000 \\
\hline A & $\mathrm{A}_{2}$ & Simple sugars & $100-300$ & 1000 \\
\hline $\mathrm{B}_{1}$ & $\mathrm{~B}_{1}$ & Starch & $10-40$ & 750 \\
\hline $\mathrm{B}_{1}$ & $\mathrm{~B}_{2}$ & $\begin{array}{l}\text { Soluble available fibre }{ }^{\mathrm{b}} \\
\text { (pectins, } \beta \text {-glucans, plant organic } \\
\text { acids and fructans) }\end{array}$ & $40-60$ & 750 \\
\hline $\mathrm{B}_{2}$ & $\mathrm{~B}_{3}$ & $\begin{array}{l}\text { Insoluble available fibre } \\
\text { (cellulose and hemicellulose) }\end{array}$ & $2-15$ & 200 \\
\hline $\mathrm{C}$ & $\mathrm{C}$ & $\begin{array}{l}\text { Unavailable fibre } \\
\text { (lignin and associated fibre) }\end{array}$ & 0 & 0 \\
\hline
\end{tabular}

a Intestinal digestibility of the rumen escape fraction.

${ }^{\mathrm{b}}$ Contains plant organic acids and may contain fructans depending on the method used to measure sugars.

listed in Table 1. In the CNCPS 5.0 and CPM Dairy 1.0 , the carbohydrate fractionation scheme assumed two fractions of non-fibre carbohydrate (NFC): the A fraction that contains organic acids and sugars, and the B1 fraction that contains soluble fibres and starch (Sniffen et al. 1992) as listed in Table 1.

During silage fermentation, some of the soluble non-cell wall components are metabolized primarily to lactic and acetic acids (McDonald et al. 1991). These silage acids are useful to the animal as a component of ME but are depleted fermentable sources of ATP for microbial growth under normal rumen conditions (Van Soest 1994). Thus, ensiling has little effect on feed energy values but can affect supply of protein to the host animal substantially by decreasing bacterial protein production. Therefore, a separation between sugars and organic or silage acids was needed. In the CPM Dairy 3.0, The CHO A fraction has been separated into silage acids (CA1) and sugars (CA2) as shown in Eqns (1)-(4).

$$
\begin{gathered}
\mathrm{CHO}_{i}=1000-\left(\mathrm{CP}_{i}+\mathrm{EE}_{i}+\mathrm{Ash}_{i}\right) \\
\mathrm{NFC}_{i}=\mathrm{CHO}_{i}-\left(\mathrm{NDF}_{i}-\frac{\mathrm{CP}_{i} \times \mathrm{NDICP}_{i}}{1000}\right) \\
\mathrm{CA}_{i}=\mathrm{OA}_{i} \times \frac{\mathrm{NFC}_{i}}{1000} \\
\mathrm{CA} 2_{i}=\operatorname{Sugar}_{i} \times \frac{\mathrm{NFC}_{i}}{1000}
\end{gathered}
$$

where $\mathrm{CHO}$ is g carbohydrate $/ \mathrm{kg}$ of $\mathrm{DM}$; $\mathrm{CP}$ is $\mathrm{g}$ crude protein $/ \mathrm{kg}$ of DM, EE is g ether extract $/ \mathrm{kg}$ of DM; Ash is $\mathrm{g} / \mathrm{kg}$ of DM; NFC is $\mathrm{g}$ non-fibre carbohydrate $/ \mathrm{kg}$ of DM, NDF is g neutral detergent fibre/kg of DM; NDICP is $\mathrm{g}$ neutral detergent insoluble $\mathrm{CP} / \mathrm{kg}$ of $\mathrm{CP}$; $\mathrm{CAl}$ is $\mathrm{g}$ carbohydrate fraction $\mathrm{A} 1 / \mathrm{kg}$ of $\mathrm{DM}$; OA is $\mathrm{g}$ organic acids from silage $/ \mathrm{kg}$ of NFC; CA2 is g carbohydrate fraction A2 $/ \mathrm{kg}$ of DM; Sugar is g simple sugars $/ \mathrm{kg}$ of NFC; and $i$ is the ith feed.

In the CNCPS 5.0 and CPM Dairy 1.0, the CB1 fraction contained starch, pectin and $\beta$-glucans. Grouping these carbohydrates together is not nutritionally correct because they may have different rates of fermentation in the rumen (Engstrom et al. 1992; Hatfield \& Weimer 1995; Hall et al. 1998), they are not precisely defined or analysed (Van Soest 1994; Pitt et al. 1996; Alderman et al. 2001; Offner \& Sauvant 2004), and it does not account for all the variability observed in NFC digestibility when various processing treatments are applied (Offner \& Sauvant 2004). Lanzas et al. (2007) provided more discussion of fractionation of carbohydrates. As shown in Table 1, some organic acids and fructans might be pooled in CB2 depending on the method used.

In the CPM Dairy 3.0, starch (CB1; Eqn (5)) has been separated from pectin and $\beta$-glucans (CB2; Eqn (6)). The composition of fraction CC (Eqn (7)) was not changed. The fraction CC consists of lignin and fibre associated with lignin, representing the material that is not fermented after $200 \mathrm{~h}$ (Van Soest et al. 2005). Carbohydrate fraction $\mathrm{C}$ is calculated as lignin $\times 2 \cdot 4$ (Van Soest et al. 2005). Remaining carbohydrate fraction is the insoluble available fibre (fraction CB3 (Eqn (8)) in the CPM Dairy 3.0), which was fraction CB2 in the CNCPS 5.0 and CPM Dairy 1.0. Several techniques for determining NDF have been developed and used (Hintz et al. 1996; Mertens 2002). If sodium sulphite is used in the determination of NDF, a variable amount of NDICP will be removed from the neutral detergent residue, depending on the feed. Therefore with this NDF analysis, the CB3 may be under-estimated when the correction for 
NDICP is applied. The B fraction carbohydrates are determined as shown in Eqns (5)-(8) below.

$$
\begin{gathered}
\mathrm{CB} 1_{i}=\mathrm{Starch}_{i} \times \frac{\mathrm{NFC}_{i}}{1000} \\
\mathrm{CB} 2_{i}=\mathrm{NFC}_{i}-\left(\mathrm{CA}_{i}+\mathrm{CA} 2_{i}+\mathrm{CB} 1_{i}\right) \\
\mathrm{CC}_{i}=\mathrm{NDF}_{i} \times \operatorname{Lignin}_{i} \times 0.024 \\
\mathrm{CB}_{i}=\left(\mathrm{NDF}_{i}-\frac{\mathrm{CP}_{i} \times \mathrm{NDICP}_{i}}{1000}\right)-\mathrm{CC}_{i}
\end{gathered}
$$

where $\mathrm{CB} 1$ is $\mathrm{g}$ carbohydrate fraction $\mathrm{B} 1 / \mathrm{kg}$ of $\mathrm{DM}$; Starch is $\mathrm{g}$ starch complexes $/ \mathrm{kg}$ of NFC; NFC is g non-fibre carbohydrate $/ \mathrm{kg}$ of DM; CB2 is $\mathrm{g}$ carbohydrate fraction $\mathrm{B} 2 / \mathrm{kg}$ of DM; CA1 is g carbohydrate fraction $\mathrm{A} 1 / \mathrm{kg}$ of $\mathrm{DM}$; CA2 is $\mathrm{g}$ carbohydrate fraction $\mathrm{A} 2 / \mathrm{kg}$ of DM; CC is $\mathrm{g}$ carbohydrate fraction $\mathrm{C} / \mathrm{kg}$ of $\mathrm{DM}$; NDF is $\mathrm{g}$ neutral detergent fibre $/ \mathrm{kg}$ of DM; NDICP is g neutral detergent insoluble $\mathrm{CP} / \mathrm{kg}$ of $\mathrm{CP}$; Lignin is $\mathrm{g}$ sulphuric acid or acid detergent lignin/kg of NDF; and $i$ is the ith feed.

\section{Lipid sub-model}

Fatty acids and glycerol are lipid compounds of nutritional significance. Crude fat is normally determined by extraction using ether; however, not all ether soluble materials are fatty acids (Van Soest 1994). As a consequence, the CPM Dairy 3.0 contains a lipid sub-model developed by Moate et al. (2004) that describes the ruminal digestion and metabolism of long-chain fatty acids (LCFA).

The lipid sub-model was developed to account for (1) intake of fatty acids, (2) ruminal lipolysis of dietary lipids, (3) ruminal biohydrogenation of fatty acids, (4) de novo synthesis of fatty acids in the rumen, (5) effects of fat on rumen digestion and fermentation and (6) intestinal digestion of fatty acids (Moate et al. 2004). The following LCFA were included in this sub-model: $n$-dodecanoic acid (lauric acid, C12:0), $n$-tetradecanoic acid (myristic acid, C14:0), $n$-hexadecanoic acid (palmitic acid, C16:0), hexadecenoic acid (palmitoleic acid, C16:1), $n$-octadecanoic acid (stearic acid, C18:0), octadecenoic acid (oleic acid, C18:1c, C18:1t); octadecadienoic acid (linoleic acid, C18:2) and octadecatrienoic acid (linolenic acid, C18:3) (Nelson \& Cox 2005).

The lipid sub-model was developed almost entirely with data from published experiments involving lactating dairy cows in which daily dietary intakes, duodenal flows and faecal outputs of individual LCFA were reported (Moate et al. 2004). The initial evaluation included seven experiments utilizing nonlactating cattle (mostly young growing steers) and one experiment utilizing lactating dairy cows. The lipid sub-model explained more than $86 \%$ of the variation between predicted and measured absorbed C12:0,
C14:0, C16:0, C18:0, C18:1t, C18:1c and C18:2. The predicted mean bias was $12 \%$ or less for $\mathrm{C} 12: 0$, C14:0, C16:0, C18:0 and C18:2. For C18:1t and C18:1c, the correlation was good $(r>0.96)$ but the mean bias was about $20 \%$. This may be a consequence of the small number of comparisons as C18:1t and $\mathrm{C} 18: 1 \mathrm{c}$ data were only reported for eight diets in two experiments. The absorption of $\mathrm{C} 16: 1, \mathrm{C} 18: 3$ and other LCFA was poorly predicted by the sub-model. However, only small amounts $(2-3 \mathrm{~g} / \mathrm{d})$ of $\mathrm{C} 16: 1$ and C18:3 were absorbed and other LCFA includes LCFA were not always reported in all experiments.

In a more recent evaluation, Moate et al. (2006) examined the ability of the lipid sub-model to predict the apparent absorption (intake minus faecal) of total LCFA in lactating dairy cows. There were two types of experiments: abomasal infusion experiments and feeding experiments. The amounts of total LCFA apparently absorbed were regressed against the reported amounts of total LCFA apparently absorbed. For the diets from the infusion experiments, the CCC $\left(r_{\mathrm{c}}\right.$; Lin 1989) was 0.923 and Pearson correlation coefficient $(r)$ was $0 \cdot 940$. For the diets from the feeding experiments, these values were $r_{\mathrm{c}}=0.975$ and $r=0.977$. These evaluations indicated that because the lipid sub-model accurately predicted the apparent absorption of total LCFA infused into the abomasum of dairy cows, appropriate intestinal absorption coefficients were used in the lipid sub-model. Furthermore, the model also accurately predicted the apparent absorption of total LCFA in the feeding experiments, suggesting the model may be correctly describing ruminal processes such as lipolysis, biohydrogenation and the de novo synthesis of LCFA that can influence apparent absorption of total LCFA.

\section{Feed dictionary}

The main goal of a feed dictionary or feed library is to provide values for feed chemical analyses needed by the model that are not available for the feeds to be used for the development of rations. The feed dictionary in the CPM Dairy 3.0 represents an evolution from the first dictionary published by Fox et al. (1990) and Sniffen et al. (1992). More than 10000 feed analyses were utilized in the development of the feed library for the CPM Dairy 3.0. Degradation rates of available NDF (CB3) were estimated from $30 \mathrm{~h}$ in vitro NDF digestion (Van Soest et al. 2000). For instance, the newly generated degradation rates of CB3 for corn silage were lower and those for alfalfa were higher than the feed dictionary values in the CPM Dairy 1.0.

Despite the effort made to provide correct values in the feed dictionary, actual chemical compositions of the feed carbohydrate and protein fractions used in CPM Dairy 3.0 should be measured in order to determine accurately intake of nutrients and prediction 
of animal performance. The values reported in a feed dictionary do not represent the mean of the chemical components of randomly selected feed samples because it assumes the chemical components are independent (Tedeschi et al. 2002). In fact, the chemical components are highly correlated (Tylutki 2002).

Some feed ingredients (e.g. ground maize) have a low variance in analysis and may not require frequent analysis. Others (e.g. forages, distillers' grains) are quite variable in composition and require frequent analysis. For some components (e.g. lignin, soluble protein, non-protein nitrogen (NPN), amino acids) there is less variance if expressed as a percentage of another component (e.g. NDF, CP, soluble protein, ruminally-undegraded protein (RUP)) than if expressed as a proportion of dry matter (DM). Additionally, some feed components such as lignin, NPN and amino acids may not be analysed and use of the feed dictionary values are facilitated when they are expressed on the basis of a fraction usually analysed or calculated.

\section{Optimization and ration formulation}

Ration formulation involves the selection of feed ingredients within a specified DMI so that nutrient supplies meet nutrient requirements at the lowest cost. Nutritional constraints are based upon application of the factorial approach to describe the requirements of cows to perform specific or multiple functions (maintenance, growth, lactation and pregnancy). Linear programming is commonly used for auto-balancing in most nutrition models (Tedeschi et al. 2000). In fact, ration formulation was one of the first applications of linear programming. Not only could solutions be found in seconds, but building on contributions of Dantzig (1951) to operational research, an array of other very helpful economic properties (shadow prices) relating to the optimal solution could be derived. Nonetheless, the suitability of linear programming for optimization depends on the linearity of the problem. The CPM Dairy 3.0 utilizes a non-linear optimization called the 'Feasible Sequential Quadratic Programming' approach (Zhou et al. 1997). Feed cost is a logical objective for ration formulation; however, other objectives may be desirable for diet formulation in the near future. These include minimization of nutrient excretion by animals and production of specific components of milk that are nutritionally valuable.

\section{Evaluation of the CPM Dairy 3.0}

The proper evaluation of a mathematical model employs a combination of statistical and empirical analyses and proper scrutiny regarding the purposes of the model that was initially conceptualized (Tedeschi 2006). Therefore, the adequacy of the CPM Dairy 3.0 was assessed based on its ability to predict milk production of high-producing dairy cows when animal and feed inputs required by the model are available. The concepts of precision and accuracy as described by Haefner (1996) and Tedeschi (2006) were utilized to determine model adequacy: precision measures how closely individual model-predicted points are within each other whereas accuracy measures how closely model-predicted points are from the true value (Haefner 1996; Tedeschi 2006). The precision and accuracy of the predictions were assessed using several statistical and modelling techniques as described by Tedeschi (2006) to guarantee a thorough evaluation of CPM Dairy 3.0 for practical applications. The main techniques used to evaluate the predictions of the model were linear regression analysis between observed and model-predicted values, CCC (Lin 1989; Liao 2003) and MSEP (Bibby \& Toutenburg 1977).

\section{Database description}

A database containing 228 individually-fed highproducing lactating dairy cows from five studies was utilized to assess the adequacy of the CPM Dairy 3.0 to predict first-limiting ME- or MP-allowable milk production. The database contained adequate information on feed composition and intake, animal description and performance, and environment information necessary to predict milk production with CPM Dairy. Study 1 had 36 primiparous and 40 multiparous Holstein cows fed wet corn gluten feed over 2 years (Kononoff et al. 2006) at the University of Nebraska-Lincoln Dairy Research Unit. Only the post-peak milk production data were utilized in the evaluation. Study 2 consisted of 23 multiparous and 16 primiparous Holstein cows averaging 263 days in milk and $614 \mathrm{~kg} \mathrm{BW}$. These cows received three levels of CP (low, medium and high) in a total mixed ration (TMR) for 4 weeks (Ruiz et al. 2002). Study 3 was comprised of 60 multiparous and 21 primiparous Holstein cows (Stone 1996). Cows from Study 3 were fed three treatments to evaluate soy hulls as forage or concentrate replacement over a 14 week period. Study 4 consisted of 15 multiparous Holstein cows averaging 126 days in milk and $560 \mathrm{~kg} \mathrm{BW}$ that were fed fresh-cut orchardgrass (Dactylus glomerata L.) and a concentrate mix with or without Rumensin ${ }^{\mathrm{TM}}$ for 3 weeks (Ruiz et al. 2001). Studies 2, 3 and 4 were conducted at the Cornell University Teaching and Research Centre. Study 5 was conducted at the experimental station of the Brazilian Agricultural Research Corporation (EMBRAPA) at Coronel Pacheco, MG (Brazil) with 14 lactating Holstein cows in a free-stall confinement (Fernando C. F. Lopes, unpublished). Maize silage was offered ad libitum while the concentrate mixture was fed based on the milk production level $(4 \cdot 08-8 \cdot 16 \mathrm{~kg}$ of $\mathrm{DM} / \mathrm{d})$. Maize silage and concentrate mixture DMI was measured daily for 5 consecutive days using individual, electronic feeders 
(Calan gate system). Cows were mechanically milked twice per day (06.00 and $14.00 \mathrm{~h}$ ) and milk production and milk composition (fat, protein and solids) were determined daily. Dietary ingredients were individually analysed for nutrients necessary to estimate ME and MP using CPM Dairy 3.0. The observed DMI was used to predict ME and MP allowable milk because the use of predicted DMI would cause two uncertainties in predicting milk production: prediction of intake and subsequent milk production.

The LCFA and degradation rates of the feeds used to perform these simulations were set to match comparable feeds listed in the CPM Dairy 3.0 feed dictionary; all other feed compositions were measured as indicated.

\section{Statistical methods}

A random coefficients model (Littell et al. 2006) was used to combine model predictions of the five studies using PROC MIXED of SAS (Littell et al. 2006). Observed milk production was regressed on modelpredicted milk production, assuming study as random effects and unstructured variance-(co)variance matrix, as shown in Eqn (9). Adjusted observed milk production was computed as the sum of fixed effects and uncontrolled-random error. Similar analysis was performed for observed and model-predicted DMI for all five studies included in the evaluation data set.

$$
\text { ObservedMilk }_{i j}=a_{i}+b_{i} \times \text { PredictedMilk }_{i j}+e_{i j}
$$

where:

$$
\begin{aligned}
\left(\begin{array}{c}
a_{i} \\
b_{i}
\end{array}\right) & \sim \operatorname{iid} N\left(\left(\begin{array}{c}
\beta_{0} \\
\beta_{1}
\end{array}\right), \Psi\right) \\
\Psi & =\left(\begin{array}{cc}
\sigma_{a}^{2} & \sigma_{a b} \\
\sigma_{a b} & \sigma_{b}^{2}
\end{array}\right) \\
e_{i j} & \sim i i d N\left(0, \sigma_{e}^{2}\right)
\end{aligned}
$$

The variance component analysis of fixed effects (model predictions, $R_{\text {FixedEffects) and study effects }}^{2}$ $\left(R_{\text {RandomEffects }}^{2}\right)$ in explaining the observed milk production was assessed based on coefficients of partial determination (Eqn (10)). The coefficients of partial determination were estimated by regressing observed milk production on fixed effects, study effects and uncontrolled-random error (Neter et al. 1996) using PROC REG of SAS (SAS Inst., Cary, NC) with options PCORR1 (for sequential sum of squares) and PCORR2 (for partial sum of squares).

$$
\begin{aligned}
& R_{\text {FixedEffects }}^{2}=\frac{\operatorname{SSR}(\text { FixedEffects } / \text { RandomEffects })}{\operatorname{SSE}(\text { RandomEffects })} \\
& R_{\text {RandomEffects }}^{2}=\frac{\text { SSR }(\text { RandomEffects } / \text { FixedEffects })}{\operatorname{SSE}(\text { FixedEffects })}
\end{aligned}
$$

where SSR(FixedEffects/RandomEffects) is partial sum of squares of regression of fixed effects when random effects was in the model, SSE(RandomEffects) is sum of squares of error when random effects was the only independent variable in the statistical model, SSR(RandomEffects/FixedEffects) is partial sum of squares of regression of random effects when fixed effects was in the model and SSE(FixedEffects) is sum of squares of error when fixed effects was the only independent variable in the statistical model.

\section{RESULTS AND DISCUSSION}

\section{Assessing the adequacy of model prediction of intake}

The analysis of the random coefficients model between observed and model-predicted DMI indicated no significant variance for the intercept $(P=0 \cdot 138)$ and for the slope $(P=0 \cdot 202)$, suggesting no interaction between intercept or slope with study. When the random study effects were removed from the observed DMI and regressed against model-predicted DMI (St-Pierre 2001), an $R^{2}$ of $0 \cdot 63$, root of mean square error (MSE) of $2.62 \mathrm{~kg} / \mathrm{d}$, mean bias of $2.14 \mathrm{~kg} / \mathrm{d}$ $(P<0.001)$, root of MSEP of $3.4 \mathrm{~kg} / \mathrm{d}(0.15$ of the observed mean) and model accuracy (as measured by the $\mathrm{Cb}$ statistic) of 0.82 were observed.

Even though the regression of observed on modelpredicted DMI were parallel (no interaction in the slope $\times$ study, $P=0 \cdot 202$ ), individual regressions by study indicated that CPM Dairy predictions of DMI were not uniform. The coefficient of determination varied from 0.34 (study 1) to 0.81 (study 5) and the root of MSE ranged from 1.06 to $3.47 \mathrm{~kg} / \mathrm{d}$. Intake is controlled by a complex and multifactorial system (Forbes 2003) that is not fully understood. There are short- (Allen 2000) and long-term (Bauman 2000) effects that control the intake of dairy cows. The prediction of DMI by the CPM Dairy 3.0 is based on the equations developed by Roseler et al. (1997) and Fox et al. (2004). These equations are empirical and static by nature with adjustments for BW, week of lactation, days pregnant and milk protein yield $(\mathrm{kg} / \mathrm{d})$, as described by Fox et al. (2004).

It is almost impossible to construct equations that will accurately predict DMI under all management, feeding and environmental conditions. The DMI predictions by the CPM Dairy model are intended as guidelines. Rations should be formulated on the basis of actual DMI. However, even when there are accurate records of feed delivered and unconsumed feed, actual DMI will often be over-estimated under field conditions. This is likely to occur because of the inability to account for feed wastes such as feed thrown out of bunks, losses across feed alleys and feed wasted into the animal area. 
Table 2. Summary of model adequacy statistics between observed and model-predicted milk production values

\begin{tabular}{|c|c|c|c|c|c|c|c|c|c|}
\hline \multirow[b]{2}{*}{ Study ${ }^{b}$} & \multicolumn{9}{|c|}{ Statistics $^{\text {a }}$} \\
\hline & $\mathrm{N}$ & $R^{2}$ & $\operatorname{MB}(\mathrm{kg} / \mathrm{d})$ & $\mathrm{Cb}$ & $\mathrm{CCC}$ & $\operatorname{RMSEP}(\mathrm{kg} / \mathrm{d})$ & $U_{\mathrm{M}}$ & $U_{\mathrm{S}}$ & $U_{\mathrm{R}}$ \\
\hline 1 & 79 & $0 \cdot 33$ & $0 \cdot 64$ & 0.993 & $0 \cdot 57$ & $6 \cdot 80$ & $0 \cdot 9$ & $28 \cdot 0$ & $71 \cdot 1$ \\
\hline 2 & 39 & $0 \cdot 59$ & $-0 \cdot 74$ & 0.986 & $0 \cdot 76$ & $4 \cdot 40$ & $4 \cdot 7$ & $17 \cdot 7$ & $77 \cdot 6$ \\
\hline 3 & 81 & 0.74 & 0.48 & 0.979 & $0 \cdot 84$ & $4 \cdot 12$ & $1 \cdot 4$ & $31 \cdot 6$ & $67 \cdot 0$ \\
\hline 4 & 15 & 0.69 & $-0 \cdot 34$ & 0.937 & $0 \cdot 78$ & $3 \cdot 11$ & $1 \cdot 2$ & 4.9 & 93.9 \\
\hline 5 & 14 & $0 \cdot 79$ & $4 \cdot 6$ & 0.689 & $0 \cdot 61$ & $5 \cdot 08$ & $80 \cdot 8$ & $3 \cdot 5$ & $15 \cdot 7$ \\
\hline \multicolumn{10}{|l|}{ All ${ }^{\mathrm{c}}$} \\
\hline Unadj & 228 & $0 \cdot 80$ & $0 \cdot 52$ & 0.997 & $0 \cdot 89$ & $5 \cdot 14$ & $1 \cdot 0$ & $11 \cdot 7$ & $87 \cdot 3$ \\
\hline Adj & 228 & 0.79 & $0 \cdot 04$ & 0.981 & $0 \cdot 87$ & $5 \cdot 22$ & $0 \cdot 0$ & $33 \cdot 5$ & $66 \cdot 5$ \\
\hline
\end{tabular}

a $\mathrm{MB}=$ mean bias ( $\mathrm{kg} / \mathrm{d}) ; \mathrm{Cb}=$ Lin's (1989) accuracy; CCC $=$ Lin's (1989) concordance correlation coefficient;

$\mathrm{RMSEP}=$ root of mean square error of prediction $(\mathrm{kg} / \mathrm{d})$; and $U_{\mathrm{M}}, U_{\mathrm{S}}$ and $U_{\mathrm{R}}$ are percent decompositions of MSEP due to mean bias, systematic bias and random errors (Tedeschi 2006).

b 1 = Kononoff et al. (2006), 2 = Ruiz et al. (2002), $3=$ Stone (1996), $4=$ Ruiz et al. (2001) and 5=EMBRAPA (Fernando C. F. Lopes, unpublished).

${ }^{\mathrm{c}}$ Observed milk production values are unadjusted (Unadj) or adjusted (Adj) for random effects of studies.

The evaluation indicated an unacceptable variation in predicting intake of lactating dairy cows under field conditions. It is possible that mechanistic and dynamic models might include short- and long-term factors (Illius \& Jessop 1996; Allen et al. 2005) affecting DMI in ruminants and may improve its DMI predictability.

\section{Assessing the adequacy of model prediction of milk production}

Across all studies, an overall regression between observed and model-predicted milk yield indicated the CPM Dairy 3.0 was able to account for $79.8 \%$ of the variation in observed milk yield with a mean bias of $0.52 \mathrm{~kg} / \mathrm{d}$ of milk $(P>0.124)$ when observed DMI was inputted in the model. The mean bias was approximately $1.6 \%$ of model-predicted milk yield; $\mathrm{CCC}$ of 0.89 ( $\mathrm{Cb}$ of 0.997$)$, and root of mean square error of prediction (RMSEP) $5.14 \mathrm{~kg} / \mathrm{d}(15.9 \%$ of the observed mean) in which 0.87 of the MSEP was due to random errors, $0 \cdot 12$ was due to systematic bias and only 0.01 was due to mean bias (Table 2). This analysis suggests that further improvements in the model may be possible by accounting for more of the variation and the level of milk production may slightly affect the model prediction. The mean and standard error of observed and model-predicted milk production were $32.3 \pm 0.71$ and $31.8 \pm 0.75 \mathrm{~kg} / \mathrm{d}$. The intercept $(5 \cdot 47)$ and slope $(0.84)$ of the regression were simultaneously different from zero and unity $(P<0 \cdot 001)$, respectively. These results were similar to those reported by Fox et al. (2004) when evaluating the CNCPS model.
The milk production data used in the present evaluation were derived from lactating cows raised under diverse production and management situations, but it represents the post-peak milk production, not the entire lactation period. Macciotta et al. (2004) have indicated an independency (weak correlation) between the increasing rate of milk yield in the first part of the lactation and the declining rate of milk yield after the lactation peak, suggesting that a change in milk yield could be the result of changing either rate. Therefore, a high milk yield prior to the peak of milk production may not guarantee a high milk yield during the post-peak period. Because the post-peak milk production represents the majority of the milk produced during the lactation of a cow and the variation due to metabolic and physiological changes associated with transition phase (Hayirli et al. 2003; Overton \& Waldron 2004) and the independency between the first and second phases of the lactation curve, only post-peak milk production was used in the current evaluation.

Despite the relatively high precision $\left(R^{2}\right)$ of the overall regression, amongst studies, the precision varied from 0.33 to 0.79 (Table 2) even though the mean bias was relatively low and accuracy was high. The discrepancy in low precision and high RMSEP suggest models based on the CNCPS framework have a good ability to accurately predict the mean when large sample sizes are used, but individual animal predictions may not be satisfactory. The decomposition of the MSEP indicated the source of error was not consistent amongst studies (Table 2). Chaves et al. (2006) reported a low precision with no mean 
bias of CNCPS-based models in predicting milk production.

The CPM Dairy 3.0 predicted that $0 \cdot 76(n=173$ cows) of the milk production was limited by protein (MP allowable milk) and $0 \cdot 24(n=55$ cows) was limited by energy (ME allowable milk). Changes in BCS might have affected the prediction of the first-limiting ME or MP allowable milk as shown by Tedeschi et al. (2006). The extent of this BCS change depends upon energy reserves at calving. This is because under-conditioned cows consume more feed and mobilize less body reserves than overconditioned cows (Overton \& Waldron 2004), which will consume less feed. The magnitude of the energy/ protein loss or gain may be indicated and monitored in terms of predicted BCS changes. When cows do not lose, or even gain, BCS during the early stages of the lactation cycle, this may reflect inadequate MP, especially if milk production does not achieve a high peak but is relatively a lower peak following parturition (Garnsworthy \& Topps 1982; Garnsworthy \& Jones 1987).

Figure 1 depicts the frequency and distributions of observed and model-predicted milk production. The data had slightly different distributions as assessed by the $\chi^{2}$ (Figs $1 \mathrm{~A}$ and $1 \mathrm{~B}$ ). Based on the KolmogorovSmirnov ranking analysis (Kolmogoroff 1933), the observed milk production had a Weibull distribution whereas the model-predicted had a normal distribution. This is an evaluation of the goodness-of-fit of the model in which we tested whether observed and model-predicted milk productions had the same population distribution. The distributions were similar but more points might be needed to obtain a normal distribution for the observed dataset and secure an adequate level for the Type II error - the error of accepting model adequacy when, in fact, models differ (Tedeschi 2006).

The null model likelihood ratio test indicated a significant improvement over the model consisting of no random effects and a homogeneous residual error $(P<0 \cdot 001)$. In fact, the random coefficients model analysis indicated that study 1 had an intercept $(P=0.029)$ and slope $(P=0 \cdot 041)$ different from all other studies. Even though intercepts and slopes of the random effects were negatively correlated $(-0 \cdot 62)$, they were not different from zero $(P=0 \cdot 403)$. Similarly, the variances of intercepts (29.48) and slopes $(0 \cdot 016)$ of the random effects were not different from zero $(P=0 \cdot 150$ and $0 \cdot 214$, respectively). Nonetheless, this indicates that adjustment for study effects was needed.

The decomposition of the total sum of squares $(\mathrm{SS}=26$ 032.4) into fixed effects (SSFxd), random effects of studies (SSRnd), and uncontrolledrandom errors (SSE), reduced the SSE from 5264.2 $(\mathrm{SSFxd}+\mathrm{SSE})$ to $4135 \cdot 8$ (SSFxd + SSRnd + SSE), indicating that SSRnd was responsible for 0.21 of
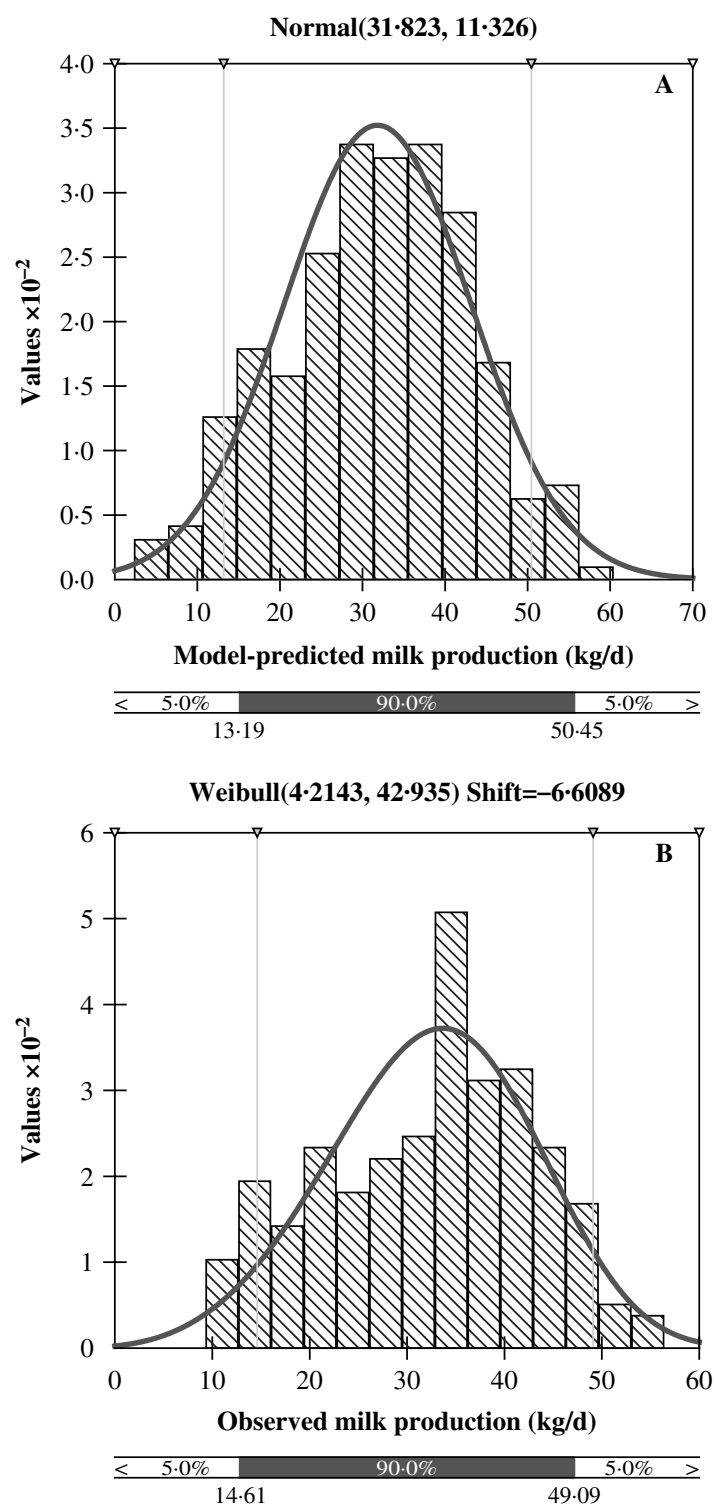

Fig. 1. Histogram and normal distribution of (A) observed and (B) CPM Dairy-predicted milk production using the data of five independent studies. The $90 \%$ confidence interval is shown by the vertical lines and the curve shows the bell shape of a normal distribution. Analyses were done with @ Risk 4.5.7 (Palisade, Newfield, NY).

the SSE. Indeed, the partial coefficient of determination (Neter et al. 1996) confirmed that random effects of studies was $0 \cdot 21$ and fixed effects was $0 \cdot 72$. Therefore, the majority of the SS of the regression between observed and model-predicted milk production was accounted for by the CPM Dairy 3.0 model. 
A
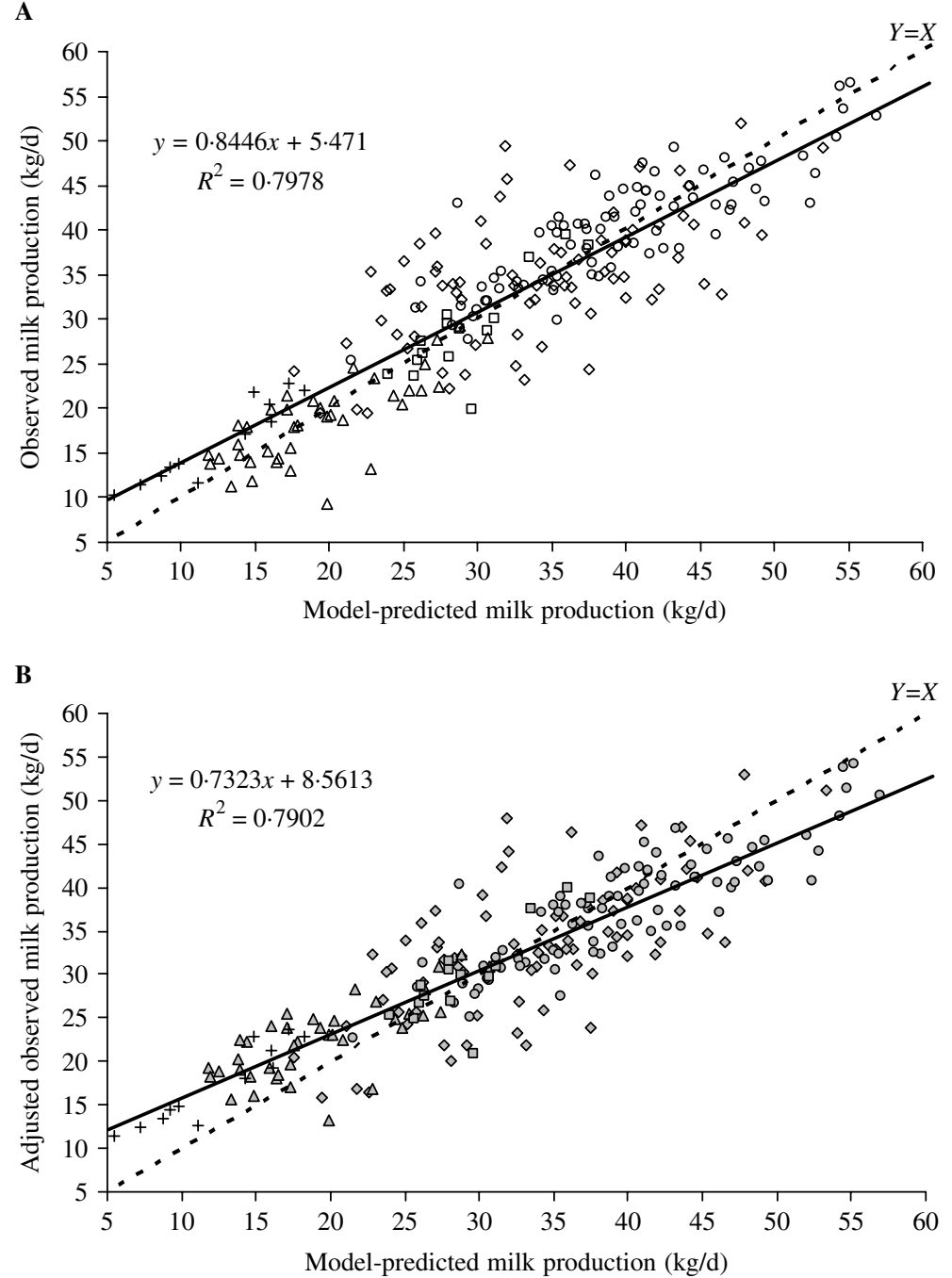

Fig. 2. Relationship of (A) unadjusted and (B) adjusted observed milk production for study effects to model-predicted milk production with data from five independent studies ( $\diamond=$ Kononoff et al. (2006); $\triangle=$ Ruiz et al. (2002); $\bigcirc=$ Stone (1996); $\square=$ Ruiz et al. (2001); and +=EMBRAPA (Fernando C. F. Lopes, unpublished) using the CPM Dairy v. 3.0 model. The solid line is the regression between $Y$ and $X$ and the dashed line is the $Y=X$ line).

These analyses suggested that when fixed effects (CPM Dairy predictions) and random effects of studies were combined into the same statistical model, $0 \cdot 84[(26032 \cdot 4-4135 \cdot 8) / 26032 \cdot 4]$ of the variation was explained. Therefore, based on these analyses, an adjusted observed milk production was calculated removing the random effects of studies (St-Pierre 2001). The adjusted observed milk production was comprised of the fixed effects (CPM Dairy predictions) plus the uncontrolled-random error (residue) of the random coefficients model.
Table 2 lists the statistics of the model accuracy using the adjusted observed milk production. As expected, the coefficient of determination $\left(R^{2}\right.$ of 0.79$)$, accuracy $(\mathrm{Cb}$ of 0.98$)$, CCC (0.87) and RMSEP $(5 \cdot 22 \mathrm{~kg} / \mathrm{d})$ remained relatively unaltered; but mean bias was significantly reduced from 0.52 to $0.04 \mathrm{~kg} / \mathrm{d}$. This analysis indicated that removing the random effects of studies further demonstrated the ability of the CPM Dairy model to predict the average milk production of lactating Holstein cows without changing precision and accuracy. The decomposition of the 
MSEP indicated an increase in the proportion of systematic bias compared to the unadjusted data, likely due to the broad aspect of our database that contained climate effects (tropical $v$. temperate regions), production level (high- $v$. low-producing cows), first limiting component (energy- $v$. protein-deficient rations) and different ration ingredients and genetics.

Figure 2 depicts the relationship of unadjusted and adjusted observed milk production $v$. modelpredicted milk production of the 228 lactating dairy cows. The simultaneous $F$-test indicated the intercept and slope of both the observed milk production (5.47 and 0.84 , respectively) and for observed milk production adjusted for study effects (8.56 and $0 \cdot 73$, respectively) were different from zero and one $(P<0 \cdot 001)$, respectively. This analysis supports those statistics listed in Table 2.

\section{IMPLICATIONS}

Based on the model evaluations performed in the current study, it was concluded that the CPM Dairy model accurately predicts nutrient requirements and diet ME and MP supply in lactating dairy cattle at the farm level when feed intake and content of carbohydrate and protein fractions can be adequately measured or estimated. These predictions allow for accurate formulation of diets to meet energy and protein requirements of lactating dairy cows, which minimizes cost and nitrogen excretion per amount of milk produced. Further improvements in the CNCPS-based models should include accounting for more of individual variability of animals and improvements in the prediction of feed intake for use when it is not known.

\section{REFERENCES}

Alderman, G. (2001). A critique of the Cornell Net Carbohydrate and Protein System with emphasis on dairy cattle. 1. The rumen model. Journal of Animal and Feed Sciences 10, 1-24.

Allen, M. S. (2000). Effects of diet on short-term regulation of feed intake by lactating dairy cattle. Journal of Dairy Science 83, 1598-1624.

Allen, M. S., Bradford, B. J. \& Harvatine, K. J. (2005). The cow as a model to study food intake regulation. Annual Review Nutrition 25, 523-547.

Bauman, D. E. (2000). Regulation of nutrient partitioning during lactation: homeostasis and homeorhesis revisited. In Ruminant Physiology: Digestion, Metabolism, Growth and Reproduction (Ed. P. B. Cronjé), pp. 311-328. New York: CABI Publishing.

Bibby, J. \& Toutenburg, H. (1977). Prediction and Improved Estimation in Linear Models. Berlin, Germany: John Wiley and Sons.

Boston, R. C., Fox, D. G., Sniffen, C. J., Janczewski, R., Munsen, R. \& Chalupa, W. (2000). The conversion of a scientific model describing dairy cow nutrition and production to an industry tool: the CPM Dairy project. In Modelling Nutrient Utilization in Farm Animals (Eds J. P. McNamara, J. France \& D. Beever), pp. 361-377. Oxford: CABI Publishing.

Chalupa, W. \& Boston, R. (2003). Development of the CNCPS and CPM models: the Sniffen affect. In Proceedings of Cornell Nutrition Conference for Feed Manufacturers, pp. 15-24. Syracuse, NY: New York State College of Agriculture and Life Sciences, Cornell University.

Chaves, A. V., Brookes, I. M., Waghorn, G. C., Woodward, S. L. \& Burke, J. L. (2006). Evaluation of Cornell Net Carbohydrate and Protein System predictions of milk production, intake and liveweight change of grazing dairy cows fed contrast silages. Journal of Agricultural Science, Cambridge 144, 85-91.

DANTZig, G. B. (1951). A proof of the equivalence of the programming problem and the game problem. In Activity Analysis of Production and Allocation (Ed. T. C. Koopmans), pp. 330-335. New York, NY: John Wiley and Sons.
Engstrom, D. F., Mathison, G. W. \& Goonewardene, L. A. (1992). Effect of $\beta$-glucan, starch, and fibre content and steam vs. dry rolling of barley grain on its degradability and utilisation by steers. Animal Feed Science and Technology 37, 33-46.

Forbes, J. M. (2003). The multifactorial nature of food intake control. Journal of Animal Science 81, E139-E144.

Fox, D. G., Sniffen, C. J., O’connor, J. D., Russell, J. B. \& Van Soest, P. J. (1990). The Cornell Net Carbohydrate and Protein System for Evaluating Cattle Diets, No. 34. Ithaca, NY: Cornell University Agricultural Experiment Station.

Fox, D. G., Tedeschi, L. O., Tylutki, T. P., Russell, J. B., Van Amburgh, M. E., Chase, L. E., Pell, A. N. \& Overton, T. R. (2004). The Cornell Net Carbohydrate and Protein System model for evaluating herd nutrition and nutrient excretion. Animal Feed Science and Technology 112, 29-78.

Garnsworthy, P. C. \& Jones, G. P. (1987). The influence of body condition at calving and dietary protein supply on voluntary food intake and performance in dairy cows. Animal Production 44, 347-353.

Garnsworthy, P. C. \& Topps, J. H. (1982). The effect of body condition of dairy cows at calving on their food intake and performance when given complete diets. Animal Production 35, 113-119.

Haefner, J. W. (1996). Modeling Biological Systems: Principles and Applications. New York: Chapman and Hall.

Hall, M. B., Pell, A. N. \& Chase, L. E. (1998). Characteristics of neutral detergent-soluble fiber fermentation by mixed ruminal microbes. Animal Feed Science and Technology 70, 23-29.

Hatfield, R. D. \& Weimer, P. J. (1995). Degradation characteristics of isolated and in situ cell wall lucerne pectic polysaccharides by mixed ruminal microbes. Journal of the Science of Food and Agriculture 69, 185-196.

Hayirli, A., Grummer, R. R., Nordheim, E. V. \& Crumps, P. M. (2003). Models for predicting dry matter intake of Holsteins during the prefresh transition period. Journal of Dairy Science 86, 1771-1779. 
Hintz, R. W., Mertens, D. R. \& Albrecht, K. A. (1996). Effects of sodium sulfite on recovery and composition of detergent fiber and lignin. Journal of the Association of Official Analytical Chemists 79, 16-22.

Illius, A. W. \& Jessop, N. S. (1996). Metabolic constraints on voluntary intake in ruminants. Journal of Animal Science 74, 3052-3062.

Kolmogoroff, A. N. (1933). Sulla determinazione empirica di una legge di distribuzione. Giornale dell'Istituto Italiano degli Attuari 4, 83-91.

Kolver, E. S., Muller, L. D., Barry, M. C. \& Penno, J. W. (1998). Evaluation and application of the Cornell Net Carbohydrate and Protein System for dairy cows fed diets based on pasture. Journal of Dairy Science 81, 2029-2039.

Kononoff, P. J., Ivan, S. K., Matzke, W., Grant, R. J., Stock, R. A. \& Klopfenstein, T. J. (2006). Milk production of dairy cows fed wet corn gluten feed during the dry period and lactation. Journal of Dairy Science 89, 2608-2617.

Lanzas, C., Sniffen, C. J., Seo, S., Tedeschi, L. O. \& Fox, D. G. (2007). A revised CNCPS feed carbohydrate fractionation scheme for formulating rations for ruminants. Animal Feed Science and Technology 136, 167-190.

LiAo, J. J. Z. (2003). An improved concordance correlation coefficient. Pharmaceutical Statistics 2, 253-261.

LiN, L. I.-K. (1989). A concordance correlation coefficient to evaluate reproducibility. Biometrics 45, 255-268.

Littell, R. C., Milliken, G. A., Stroup, W. W., Wolfinger, R. D. \& Schabenberger, O. (2006). SAS for Mixed Models. 2nd edn. Cary, NC: SAS Institute.

Macciotta, N. P. P., Vicario, D., Di Mauro, C. \& CappioBorlino, A. (2004). A multivariate approach to modeling shapes of individual lactation curves of cattle. Journal of Dairy Science 87, 1092-1098.

McDonald, P., Henderson, A. R. \& Heron, S. J. E. (1991). The Biochemistry of Silage. 2nd edn. London, UK: Chalcombe Publications.

Mertens, D. R. (2002). Gravimetric determination of amylase-treated neutral detergent fiber in feeds with refluxing in beakers or crucibles: collaborative study. Journal of AOAC International 85(6), 1217-1240.

Moate, P. J., Boston, R. C., Lean, I. J. \& Chalupa, W. (2006). Short communication: Further validation of the fat sub-model in the Cornell-Penn-Miner dairy model. Journal of Dairy Science 89, 1052-1056.

Moate, P. J., Chalupa, W., Jenkins, T. G. \& Boston, R. C. (2004). A model to describe ruminal metabolism and intestinal absorption of long chain fatty acids. Animal Feed Science and Technology 112, 79-105.

Nelson, D. L. \& Cox, M. M. (2005). Lehninger Principles of Biochemistry. 4th edn. New York, NY: W.H. Freeman and Company.

Neter, J., Kutner, M. H., Nachtsheim, C. J. \& Wasserman, W. (1996). Applied Linear Statistical Models. 4th edn. Boston: McGraw-Hill Publishing Co.

Newman, S., Lynch, T. \& Plummer, A. A. (2000). Success and failure of decision support systems: learning as we go. Journal of Animal Science 77, 1-12.

Offner, A. \& Sauvant, D. (2004). Comparative evaluation of the Molly, CNCPS, and LES rumen models. Animal Feed Science and Technology 112, 107-130.

Overton, T. R. \& Waldron, M. R. (2004). Nutritional management of transition dairy cows: strategies to optimize metabolic health. Journal of Dairy Science 87, E105-E119.

Pitt, R. E., Van Kessel, J. S., Fox, D. G., Pell, A. N., Barry, M. C. \& Van Soest, P. J. (1996). Prediction of ruminal volatile fatty acids and $\mathrm{pH}$ within the net carbohydrate and protein system. Journal of Animal Science 74, 226-244.

Roseler, D. K., Fox, D. G., Chase, L. E., Pell, A. N. \& Stone, W. C. (1997). Development and evaluation of equations for prediction of intake for lactating Holstein dairy cows. Journal of Dairy Science 80, 878-893.

Ruiz, R., Albrecht, G. L., Tedeschi, L. O., Jarvis, G., Russell, J. B. \& Fox, D. G. (2001). Effect of monensin on the performance and nitrogen utilization of lactating dairy cows consuming fresh forage. Journal of Dairy Science 84, 1717-1727.

Ruiz, R., Tedeschi, L. O., Marini, J. C., Fox, D. G., Pell, A. N., Jarvis, G. \& Russell, J. B. (2002). The effect of a ruminal nitrogen $(\mathrm{N})$ deficiency in dairy cows: evaluation of the Cornell net carbohydrate and protein system ruminal N deficiency adjustment. Journal of Dairy Science 85, 2986-2999.

Sniffen, C. J., O'Connor, J. D., Van Soest, P. J., Fox, D. G. \& Russell, J. B. (1992). A net carbohydrate and protein system for evaluating cattle diets: II. Carbohydrate and protein availability. Journal of Animal Science 70, 3562-3577.

St-Pierre, N. R. (2001). Integrating quantitative findings from multiple studies using mixed models methodology. Journal of Dairy Science 84, 741-755.

Stone, W. C. (1996). Applied topics in dairy cattle nutrition: 1. Soyhulls as either a forage or concentrate replacement in early lactation Holstein dairy cattle, 2. Evaluation of the Cornell Net Carbohydrate and Protein System's metabolizable protein requirement as supply in Holstein dairy cattle, 3. In vitro effects of lipids on fermentation systems. Ph.D. Dissertation, Cornell University.

Tedeschi, L. O. (2006). Assessment of the adequacy of mathematical models. Agricultural Systems 89, 225-247.

Tedeschi, L. O., Fox, D. G., Chase, L. E. \& Wang, S. J. (2000). Whole-herd optimization with the Cornell Net Carbohydrate and Protein System. I. Predicting feed biological values for diet optimization with linear programming. Journal of Dairy Science 83, $2139-2148$

Tedeschi, L. O., Fox, D. G., Pell, A. N., Lanna, D. P. D. \& Born, C. (2002). Development and evaluation of a tropical feed library for the Cornell Net Carbohydrate and Protein System model. Scientia Agricola 59, 1-18.

Tedeschi, L. O., Fox, D. G., Sainz, R. D., Barioni, L. G., Medeiros, S. R. \& Boin, C. (2005). Using mathematical models in ruminant nutrition. Scientia Agricola 62, 76-91.

Tedeschi, L. O., Seo, S., Fox, D. G. \& Ruiz, R. (2006). Accounting for energy and protein reserve changes in predicting diet-allowable milk production in cattle. Journal of Dairy Science 89, 4795-4807.

TYLUTKI, T. P. (2002). Improving herd nutrient management on dairy farms: (1) Daily milk production variance in high producing cows as an indicator of diet nutrient balance. (2) On-farm six sigma quality management of diet nutrient variance. (3) Feedstuff variance on a commercial dairy and the predicted associated milk production variance. 
(4) A model to predict cattle nitrogen and phosphorus excretion with alternative herd feed programs. (5) Accounting for uncertainty in ration formulation. Ph.D. Dissertation, Cornell University.

Tylutki, T.P., Fox, D. G. \& McMahon, M. (2004). Implementation of nutrient management planning on a dairy farm. The Professional Animal Scientist 20, 58-65.

VAN SOEST, P. J. (1994). Nutritional Ecology of the Ruminant. 2nd edn. Ithaca, NY: Comstock Publishing Associates.

Van Soest, P. J., Van Amburgh, M. E., Robertson, J. B. \& KNAUS, W. F. (2005). Validation of the $2 \cdot 4$ times lignin factor for ultimate extent of NDF digestion, and curve peeling rate of fermentation curves into pools. In Proceedings of Cornell Nutrition Conference for Feed Manufacturers, pp. 139-150. Syracuse, NY: New York
State College of Agriculture and Life Sciences, Cornell University.

Van Soest, P. J., Van Amburgh, M. E. \& Tedeschi, L. O. (2000). Rumen balance and rates of fiber digestion. In Proceedings of Cornell Nutrition Conference for Feed Manufacturers, pp. 150-166. Rochester, NY: New York State College of Agriculture and Life Sciences, Cornell University.

Zhou, J. L., Tits, A. L. \& Lawrence, C. T. (1997). User's Guide for FFSQP version 3.7: A FORTRAN Code for Solving Constrained Nonlinear (Minimax) Optimization Problems, Generating Iterates Satisfying All Inequality and Linear Constraints, p. 46. University of Maryland, College Park, MD: Electrical Engineering Department and Institute for Systems Research. 